\title{
Comparison of Measured and Calculated Carboxylation Rate, Electron Transfer Rate and Photosynthesis Rate Response to Different Light Intensity and Leaf Temperature in Semi-closed Greenhouse with Carbon Dioxide Fertilization for Tomato Cultivation \\ Eun-Young Choi ${ }^{1}$, Young-Ae Jeong ${ }^{2}$, Seung-Hyun $\mathrm{An}^{3}$, Dong-Cheol Jang ${ }^{4}$, Dae-Hyun Kim ${ }^{5}$, Dong-Soo Lee ${ }^{6}$, Jin-Kyung Kwon ${ }^{7}$, and Young-Hoe $\mathrm{Woo}^{8 * *}$ \\ ${ }^{I}$ Professor, Department of Agricultural Science, Korea National Open University, Seoul 03087, Korea ${ }^{2}$ Graduate Student, Department of Agriculture and Life Science, Korea National Open University, Seoul 03087, Korea \\ ${ }^{3}$ Undergraduate Student, Department of Agricultural Science, Korea National Open University, Seoul 03087, Korea \\ ${ }^{4}$ Postdoctoral Researcher, Department of Horticulture, College of Agriculture and Life Science, Kangwon National University, Chuncheon 24341, Korea \\ ${ }^{5}$ Professor, Department of Biosystems Engineering, College of Agriculture and Life Science, Kangwon National University, Chuncheon 24341, Korea \\ ${ }^{6}$ Postdoctoral Researcher, Department of Agricultural Engineering, Energy and Environmental Engineering Division, Jeonju 54875, Korea \\ ${ }^{7}$ Researcher, Department of Agricultural Engineering, Energy and Environmental Engineering Division, Jeonju 54875, Korea \\ ${ }^{8}$ Professor, Department of Horticulture Environment System, Korea National College of Agriculture and Fisheries, Jeonju 54874, Korea
}

\section{반밀폐형 온실 내에서 탄산가스 시비에 따른 광강도와 엽온에 반응한 토마토 잎의 최대 카복실화율, 전자전달율 및 광합성율 실측값과 모델링 방정식에 의한 예측값의 비교}

최은영 ${ }^{1} \cdot$ 정영애 $^{2} \cdot$ 안승현 $^{3} \cdot$ 장동철 $^{4} \cdot$ 김대현 $^{5} \cdot$ 이동수 $^{6} \cdot$ 권진경 $^{7} \cdot$ 우영회 $^{8 *}$

${ }^{1}$ 한국방송통신대학교 농학과 교수, ${ }^{2}$ 한국방송통신대학교 대학원 농생명과학과 대학원생, ${ }^{3}$ 한국방송통신대학교 농학과 학부생, ${ }^{4}$ 강원대학교 원예학과 박사후연구원, ${ }^{5}$ 강원대학교 에너지공학과 교수, ${ }^{6}$ 농촌진흥청 농업과학원 박사후연구원,

${ }^{7}$ 농촌진흥청 농업과학원 연구사, ${ }^{8}$ 한국농수산대학 원예환경시스템학과 교수

생물환경조절학회지 30 권 4 호에 게재된 논문의 사사가 잘못 기재되어 있어 바로 잡습니다.

수정 전

This study was conducted with the support of the Korea Smart Farm R\&D Foundation (Project no. 118015-3) of Korea Institute of Planning and Evaluation for Technology in Food, Agriculture and Forestry.

수정 후

This study was conducted with the support of the Korea Smart Farm R\&D Foundation (Project no. 421040-04) of Korea Institute of Planning and Evaluation for Technology in Food, Agriculture and Forestry.

*Corresponding author: wooyh612@korea.kr

Received September 24, 2021; Revised October 16, 2021;

Accepted October 25, 2021 